\title{
The Effect of Classical and Jazz Background-Music on Concentration and Reading Comprehension in Young Adult Women
}

\author{
Harijadi Pramono*, Julia W Gunadi", Oeij A Adhika**, Yenni Limyati***, \\ Herlina Gisela ${ }^{* * * *}$,Vica C Dewi ${ }^{* * * *}$ \\ *Department of Physiology Faculty of Medicine Maranatha Christian University \\ **Department of Anatomy Faculty of Medicine Maranatha Christian University \\ ***Department of Skills Lab Faculty of Medicine Maranatha Christian University / \\ Medical Rehabilitation Unit Immanuel Hospital Bandung \\ *** Faculty of Medicine Maranatha Christian University \\ Jl. Prof. drg. Suria Sumantri MPH No.65 Bandung 40164 Jawa Barat Indonesia \\ Email:dokhar.1001tx@yahoo.co.id
}

\begin{abstract}
Classical and jazz music activates $\alpha$ brain wave that stimulate the excretion of $\beta$ endorphins that has a role in increasing the alertness and attention. The purpose of this study was to determine the effect of classical and jazz background-music to the concentration and reading comprehension. This is a quasi experimental study, with pre-test and post-test design, performed on 30 young adult women. The measured data were Addition and reading comprehension test scores before and while listening to music. Data were analyzed using paired $t$-test with and non paired t-test with $\alpha=0.05$. The results showed that there were highly significant differences of Addition Test score (547.73) and reading comprehension test score (80.33) with classical music background; Addition Test score (577.47) and reading comprehension test score (78.33) with jazz music background compared to pre-treatment of classical (457.57; 61.67) ( $p<0.01)$; and jazz music (538.07; 65.00) $(p<0.01)$ respectively. The comparison of both types of music showed no difference of Addition Test score and reading comprehension test score ( $p>0.05)$. We concluded classical and jazz background music improve concentration and reading comprehension in young adult women, with no significant differences in both types of background music.
\end{abstract}

Keywords: concentration, reading comprehension, background music, classical, jazz 


\title{
Pengaruh Background-Music Klasik dan Jazz terhadap Konsentrasi dan Reading Comprehension pada Perempuan Dewasa Muda
}

\author{
Harijadi Pramono*, Julia W Gunadi*, Oeij A Adhika **, Yenni Limyati ***, \\ Herlina Gisela ${ }^{* * * *}$, Vica C Dewi ${ }^{* * * *}$ \\ *Bagian Ilmu Faal Fakultas Kedokteran Universitas Kristen Maranatha \\ ** Bagian Anatomi Fakultas Kedokteran Universitas Kristen Maranatha \\ *** Bagian Skills Lab Fakultas Kedokteran Universitas Kristen Maranatha / Unit \\ Rehabilitasi Medik Rumah Sakit Immanuel Bandung \\ **** Fakultas Kedokteran Universitas Kristen Maranatha \\ Jl. Prof. drg. Suria Sumantri MPH No.65 Bandung 40164 Jawa Barat Indonesia \\ Email:dokhar.1001tx@yahoo.co.id
}

\begin{abstract}
Abstrak
Musik klasik dan jazz dapat mengaktifkan gelombang otak yang merangsang pengeluaran $\beta$-endorfin, yang memiliki peranan dalam kewaspadaan dan perhatian. Tujuan penelitian ini adalah mengetahui pengaruh klasik dan jazz terhadap konsentrasi dan reading comprehension. Penelitian ini bersifat eksperimental kuasi dengan rancangan pre-test dan posttest, dilakukan pada 30 orang perempuan dewasa muda. Data yang diukur adalah skor Addition dan reading comprehension test sebelum dan saat mendengarkan background-music klasik dan jazz. Data dianalisis menggunakan uji t berpasangan untuk melihat pengaruh dari tiap jenis background-music, dan uji t tidak berpasangan $(\alpha=0.05)$ untuk membandingkan keduanya. Hasil penelitian menunjukkan adanya perbedaan yang sangat bermakna pada skor tes Addition (547.73) dan skor reading comprehension (80.33) dengan background-music klasik; dan skor Addition test (577.47) dan skor reading comprehension (78.33) dengan background-music jazz dibandingkan dengan sebelum subjek mendengarkan background-music klasik $(457.57 ; 61.67)$ $(\mathrm{p}<0.01)$; dan jazz $(538.07 ; 65.00)(\mathrm{p}<0.01)$, secara berurutan. Perbandingan di antara kedua jenis music tersebut menunjukkan tidak ada perbedaan antara skor Addition test dan reading comprehension antara klasik dan jazz ( $\mathrm{p}>0.05)$. Simpulan penelitian ini adalah mendengarkan background-music klasik dan jazz meningkatkan konsentrasi dan reading comprehension pada perempuan dewasa muda, tanpa perbedaan bermakna pada kedua jenis background-music tersebut.
\end{abstract}

Kata kunci: konsentrasi, reading comprehension, background-music, klasik, jazz. 


\section{Pendahuluan}

Salah satu hal yang penting untuk mendapatkan pengertian yang benar saat membaca textbook ialah kemampuan untuk berkonsentrasi dan memahami dengan baik sehingga proses belajar dapat berlangsung dengan efektif. Konsentrasi adalah pemusatan perhatian atau pikiran pada suatu hal, sedangkan reading comprehension merupakan suatu proses memahami keseluruhan representasi isi teks bacaan yang dibaca. ${ }^{1}$ Setiap individu mempunyai cara tersendiri untuk dapat memaksimalkan kemampuannya dalam berkonsentrasi dan memahami bacaan. Ada sebagian yang senang membaca dalam kondisi yang tenang, namun ada juga di antaranya yang senang membaca dengan diiringi oleh background-music. ${ }^{2}$

Pengaruh berbagai jenis musik terhadap fungsi kognitif, seperti reading comprehension dan konsentrasi masih menjadi perdebatan dalam bidang ilmu neurologi. Sebagian penelitian menunjukkan hasil yang positif, namun sebagian lainnya memperlihatkan hasil yang berlawanan. ${ }^{3}$ Salah satu penelitian yang dilakukan oleh Nichols et al menunjukkan bahwa pemain musik jazz memiliki kemampuan yang lebih superior dalam kemampuan kognitif dibandingkan dengan pemusik klasik, namun penelitian yang membandingkan pengaruh background-music jazz dan klasik pada subjek yang bukan pemusik jazz ataupun klasik belum pernah dilakukan. ${ }^{4}$ Musik klasik pada umumnya sering digunakan untuk penelitian yang berhubungan dengan fungsi kognitif. Irama dan alunan musik klasik yang terdengar menstimulasi gelombang otak lebih kuat, sehingga memproduksi serotonin yang lebih banyak pula. ${ }^{2}$ Serotonin menimbulkan rasa tenang dan gembira yang membuat otak siap untuk belajar. ${ }^{5}$ Gelombang alfa yang teraktivasi saat mendengarkan musik klasik berhubungan dengan kondisi pikiran rileks dan santai dan berkorelasi dengan intelegensi. ${ }^{2,6}$

Musik jazz adalah salah satu musik yang mempunyai irama dan nada yang bersifat teratur serta dinamis sehingga berpengaruh dalam kecerdasan emosi dan intelegensi. ${ }^{7}$ Musik jazz memberikan efek flow pada pendengarnya sehingga terciptalah rasa tenang. ${ }^{8}$ Flow yang dimaksud dapat diartikan sebagai keadaan terlepas dari gangguan emosional dan membantu seseorang memfokuskan diri terhadap pekerjaannya. Flow juga menimbulkan motivasi. Apabila siswa mengalami efek flow dalam kegiatan belajar, maka diharapkan akan menghasilkan prestasi yang lebih baik. $^{7}$

Berdasarkan uraian di atas maka peneliti tertarik untuk menggali lebih jauh efek dari background-music klasik dan jazz terhadap konsentrasi dan reading comprehension. 


\section{Metode}

Penelitian ini menggunakan desain eksperimental semu (quasi) dengan rancangan pretest dan post-test. Penelitian dilakukan di Laboratorium Komputer Universitas Kristen Maranatha pada bulan Januari-September 2016. Subjek penelitian terdiri dari tiga puluh orang perempuan dewasa muda berusia 18-25 tahun, memahami tujuan dan prosedur penelitian serta secara sukarela bersedia mengikuti penelitian ini, didukung oleh surat persetujuan untuk berperan serta dalam penelitian ini. Data yang diperoleh berupa skor Addition test untuk mengukur konsentrasi dan reading comprehension test sebelum dan saat perlakuan. Selanjutnya data diolah dan dianalisis dengan metode analisis statistik uji $\mathrm{t}$ berpasangan dan tidak berpasangan dengan $(\alpha)=0.05$, menggunakan program IBM ${ }^{\circledR}$ SPSS ${ }^{\circledR}$.

Penelitian dibagi menjadi 2 hari untuk pengukuran skor Addition Test sebelum dan saat mendengarkan background-music klasik dan jazz. Hari pertama subjek mendengarkan background-music klasik dan hari kedua mendengarkan background-music jazz. Tiap subjek penelitian diminta untuk membaca tanpa mendengarkan musik klasik dan mengisi lembaran Addition Test tipe 1 yang diselesaikan dalam waktu sepuluh menit (pre-test). Setelah itu subjek penelitian diberi waktu istirahat selama lima belas menit. Kemudian subjek diminta untuk mengisi lembaran Addition Test tipe 2 sambil mendengarkan musik klasik Mozart "Sonata for two pianos in D major, K.448 - II Andante" dalam waktu sepuluh menit (post-test). Lalu dihitung skor pre-test dan post-test dan dibandingkan skornya. Hari kedua menggunakan prosedur yang sama seperti hari pertama dengan perlakuan menggunakan musik jazz karya Peter White yang berjudul Another Rainy Day. Lembar Addition Test yang dipakai pada hari kedua adalah tipe 3 untuk pre-test dan tipe 4 untuk post-test.

Setelah diberi jeda waktu seminggu, penelitian kembali dilakukan dalam 2 hari untuk pengukuran skor reading comprehension test sebelum dan saat mendengarkan backgroundmusic klasik dan jazz. Hari pertama subjek mendengarkan background-music klasik dan hari kedua mendengarkan background-music jazz. Tiap subjek penelitian diminta untuk membaca tanpa mendengarkan musik klasik dan mengisi jawaban pertanyaan yang berkaitan dengan paragraf bacaan yang berjudul Mickey Mouse dan selesai dalam waktu sebelas menit (pre-test). Setelah itu subjek penelitian diberi waktu istirahat selama lima belas menit. Kemudian subjek diminta untuk membaca dan mengisi jawaban pertanyaan yang berkaitan dengan paragraf bacaan yang berjudul Basketball sambil mendengarkan musik klasik Mozart "Sonata for two pianos in D major, K.448 - II Andante" dalam waktu sebelas menit (post-test). Lalu dihitung skor pre-test dan post-test dan dibandingkan skornya. Hari kedua menggunakan prosedur yang 
sama seperti hari pertama dengan perlakuan menggunakan musik jazz karya Peter White yang berjudul Another Rainy Day. Paragraf bacaan untuk pre-test hari kedua berjudul Bioluminescence dan untuk post-test berjudul Hydrogen. Pemilihan bacaan untuk reading comprehension ini dilakukan berdasarkan tingkat kesulitan yang setara di antara keempat bacaan tersebut, dengan memperhatikan banyaknya kosa kata baru dan tingkat kesulitan sepuluh pertanyaan dari masing-masing bacaan.

\section{Hasil}

Nilai rerata pre-test Addition Test (sebelum mendengarkan background-music klasik) sebesar 457,57, sedangkan rerata nilai post-test (saat mendengarkan background-music klasik) sebesar 547,73. Selisih nilai rerata antara sebelum dan saat mendengarkan background-music klasik sebesar 90,16. Nilai rerata pre-test Addition Test (sebelum mendengarkan backgroundmusic jazz) sebesar 538,07, sedangkan rerata nilai post-test (saat mendengarkan backgroundmusic jazz) sebesar 577,47. Selisih nilai rerata antara sebelum dan sesudah mendengarkan musik jazz sebesar 39,4. Hasil tersebut dapat dilihat pada gambar 1 berikut ini.

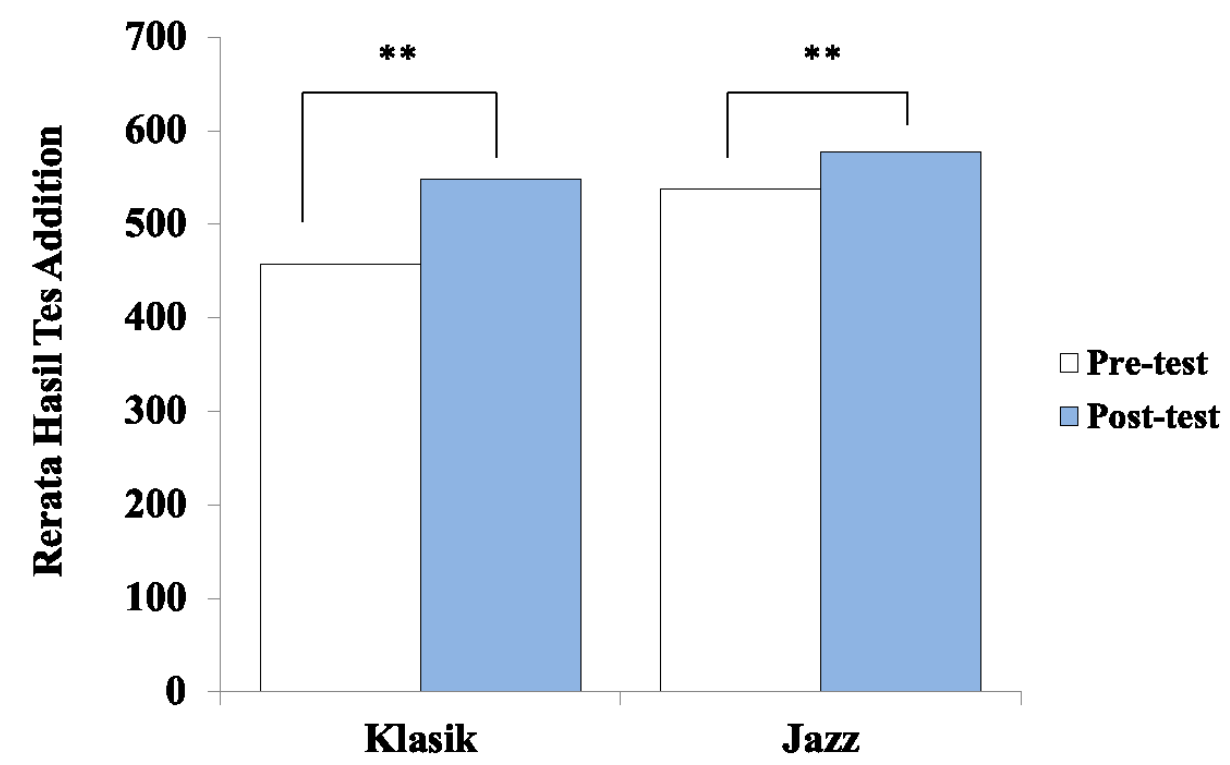

\section{Gambar 1 Grafik Rerata Hasil Addition Test Sebelum dan Saat Mendengarkan Background-music Klasik dan Jazz pada Perempuan Dewasa Muda}

Nilai rerata pre-test reading comprehension test (sebelum mendengarkan backgroundmusic klasik) sebesar 61,67, sedangkan rerata nilai post-test (saat mendengarkan backgroundmusic klasik) sebesar 80.33. Selisih nilai rerata antara sebelum dan saat mendengarkan background-music klasik sebesar 18,67, dengan nilai $\mathrm{p}<0,01$ Nilai rerata pre-test reading 
Research Article

comprehension test (sebelum mendengarkan background-music jazz) sebesar 65,00, sedangkan rerata nilai post-test (saat mendengarkan background-music jazz) sebesar 78,33. Selisih nilai rerata antara sebelum dan sesudah mendengarkan musik jazz sebesar 13,33, dengan nilai $\mathrm{p}<$ 0,01 Hasil tersebut dapat dilihat pada gambar 2 berikut ini.

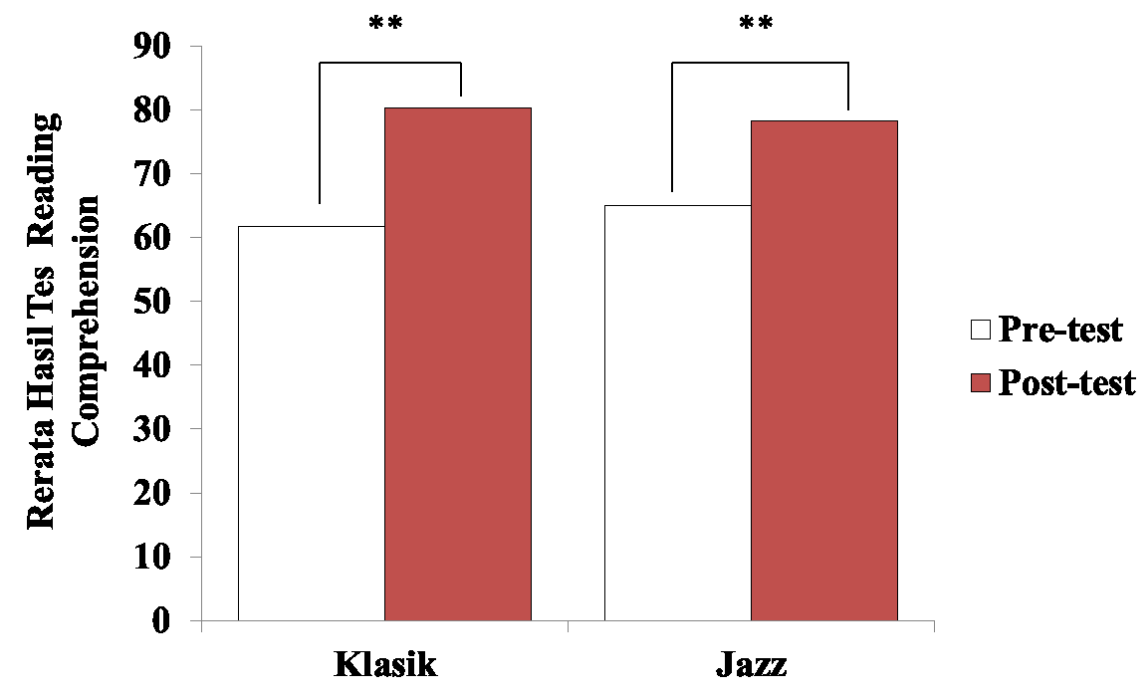

Gambar 2 Grafik Rerata Hasil Reading Comprehension Test Sebelum dan Saat Mendengarkan Background-music Klasik dan Jazz pada Perempuan Dewasa Muda

Untuk mengetahui adanya perbedaan antara kedua jenis background-music tersebut, maka dilakukan uji t test tidak berpasangan pada rerata hasil post-test Addition dan reading comprehension test, ternyata didapatkan hasil yang tidak bermakna $(\mathrm{p}>0,05)$. Hal tersebut digambarkan pada gambar 3 di bawah ini.

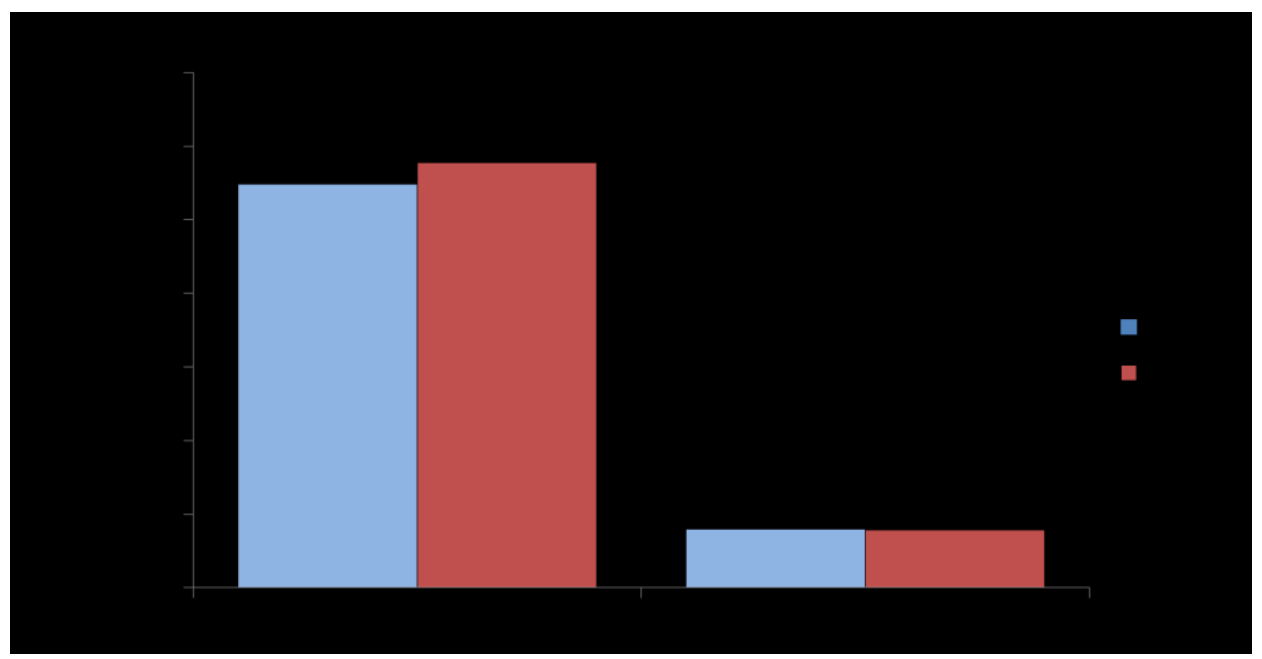

Gambar 3 Grafik Perbandingan Rerata Hasil Addition dan Reading Comprehension Test Sebelum dan Saat Mendengarkan Background-music Klasik dan Jazz pada Perempuan Dewasa Muda 


\section{Diskusi}

Gelombang otak adalah gelombang yang terekam dalam potensial listrik di dalam otak. Pada orang yang sehat, secara umum gelombang otak dapat diklasifikasikan menjadi gelombang alfa, beta, teta, dan delta. Intensitas gelombang otak terutama ditentukan oleh sejumlah neuron dan serat saraf yang meletup secara sinkron satu sama lain, dan tidak ditentukan oleh nilai total aktivitas listrik dalam otak. Gelombang alfa merupakan gelombang berirama yang timbul pada frekuensi antara 8 dan 13 siklus per detik, dan dijumpai di hampir semua rekaman EEG orang dewasa normal saat bangun dan keadaan tenang, yaitu istirahat berpikir. Gelombang beta, timbul pada frekuensi lebih rendah dari gelombang alfa, yakni 14 siklus per detik dan dapat mencapai 80 siklus per detik. Gelombang teta, mempunyai frekuensi antara empat dan tujuh siklus per detik. Gelombang ini normalnya timbul di regio parietal dan temporal anak-anak, namun dapat juga ditemukan pada stres emosional pada orang dewasa, terutama selama mengalami kekecewaan dan frustasi. Gelombang delta, memiliki frekuensi yang kurang dari 3,5 siklus per detik dan memiliki voltase dua sampai empat kali voltase tipe gelombang lainnya. Gelombang ini terjadi pada saat tidur nyenyak, pada bayi, dan pada penyakit organik otak yang parah. ${ }^{9}$

Mendengarkan musik dapat mengonversikan gelombang beta menjadi gelombang alfa sehingga meningkatkan kewaspadaaan, konsentrasi, pemahaman bacaan, dan menyeimbangkan aktivitas otak kiri dan otak kanan. Otak kiri unggul dalam hal yang logis, analitis, sekuensial, dan tugas-tugas verbal, seperti matematika, bentuk bahasa, dan filsafat serta memiliki kecenderungan memproses informasi dengan detail dan terfragmentasi. Sebaliknya, otak kanan unggul dalam keterampilan non-bahasa, terutama persepsi spasial dan artistik serta segala halhal musikal. ${ }^{10}$ Keseimbangan dan integrasi kedua belah hemisfer ini berkepentingan untuk mendapatkan persepsi yang utuh. Selain itu, konsentrasi juga dapat dipertahankan saat kita mendengarkan musik klasik Mozart selama sepuluh atau lima belas menit sehingga diharapkan dapat lebih memahami isi bacaan dengan lebih baik. ${ }^{11}$

Dari hasil penelitian yang telah dilakukan, didapatkan rerata nilai pre-test sebelum mendengarkan background-music musik klasik: Addition Test sebesar 457,57, reading comprehension test sebesar 61,67, sedangkan rerata nilai post-test saat mendengarkan background-music musik klasik: Addition Test sebesar 547,73, reading comprehension test sebesar 80,33. Selisih nilai rerata Addition Test antara sebelum dan saat mendengarkan background-music klasik sebesar 90,16, dan reading comprehension test sebesar 18,67 dengan hasil uji t berpasangan nilai $p<0,01$, yang berarti terdapat perbedaan sangat bermakna antara 


\section{Research Article}

nilai pre-test dan post-test Addition Test dan reading comprehension test saat mendengarkan background-music klasik dibandingkan dengan sebelumnya.

Penelitian serupa sebelumnya telah dilakukan oleh Nasser Rashidi dan Farman Faham tahun 2011 pada 60 siswa di Iran Language Institute (ILI). Pada penelitiannya terbukti bahwa terdapat perbedaan yang signifikan antara kinerja kelompok yang diberi perlakuan musik klasik (Mozart Sonata) dengan kinerja kelompok kontrol. Hasil tes reading comprehension pada kelompok perlakuan mengungguli kelompok kontrol. ${ }^{12}$ Penelitian lain pada tahun 2012 oleh Alexander, Firouzbakht, Glennon, dan Lang di University of Wisconsin membuktikan bahwa terdapat perbedaan yang signifikan pada jenis musik klasik terhadap skor reading comprehension. Mereka juga menyatakan bahwa jenis musik klasik memengaruhi kinerja kognitif seseorang, salah satunya adalah kemampuan konsentrasi. ${ }^{13}$ Dengan demikian, penelitian di atas mendukung hasil penelitian ini.

Hasil lain yang didapat pada penelitian ini adalah rerata nilai pre-test sebelum mendengarkan background-music musik jazz: Addition Test sebesar 538,07, reading comprehension test sebesar 65,00 , sedangkan rerata nilai post-test saat mendengarkan background-music musik jazz : Addition Test sebesar 577,47, reading comprehension test sebesar 78,33. Selisih nilai rerata Addition Test antara sebelum dan saat mendengarkan background-music jazz sebesar 39.4, dan reading comprehension test sebesar 13,33 dengan hasil uji $\mathrm{t}$ berpasangan nilai $p<0,01$, yang berarti terdapat perbedaan sangat bermakna antara nilai pre-test dan post-test Addition Test dan reading comprehension test saat mendengarkan background-music jazz dibandingkan dengan sebelumnya.

Studi mengenai efektivitas musik jazz terhadap fungsi otak telah dilaksanakan sebelumnya oleh B. Geethanjali, K. Adalarasu, dan R. Rajsekaran di India tahun 2012. Mereka menggunakan tiga jenis musik yaitu jazz, carnatic, dan hard rock. Pada studinya, didapatkan hasil bahwa terdapat perbedaan signifikan pada kekuatan gelombang alfa yang terjadi pada saat mendengarkan musik jazz dengan atau tanpa mental task. Saat gelombang alfa teraktivasi maka terjadi peningkatan kewaspadaan dan tingkat atensi. ${ }^{14}$

Perbandingan kedua pengaruh genre musik tersebut dihitung menggunakan uji t tidak berpasangan yang didapatkan nilai $p>0,05$, yang berarti tidak terdapat perbedaan antara pengaruh mendengarkan musik klasik dengan musik jazz terhadap konsentrasi dan reading comprehension pada perempuan dewasa muda.

Penelitian mengenai musik klasik, dan jazz sebelumnya telah dilakukan oleh Sarah Mac Sweeney tahun 2012 di Dun Laoghaire Institute of Art, Design \& Technology menggunakan musik klasik dan jazz sebagai bahan ujinya. Studi ini memberikan hasil yang tidak signifikan 


\section{Research Article}

pada skor tes reading comprehension terhadap kedua genre musik tersebut. ${ }^{15}$ Hal ini bertentangan dengan hasi penelitian yang didapat saat ini. Penelitian sebelumnya menggunakan musik klasik yang berbeda yaitu karangan Beethoven yang mempunyai karakteristik berbeda dengan karya Mozart. Lalu, musik jazz yang digunakan pada penelitian yang terdahulu juga berbeda dengan penelitian saat ini dan juga bertempo lebih cepat. Hal ini memungkinkan terjadinya perbedaan antara hasil penelitian terdahulu dengan penelitian saat ini.

Mendengarkan musik dapat meningkatkan kadar endorfin dan serotonin sehingga timbul perasaan bahagia dan sejahtera. Selain itu, mendengarkan musik juga mengaktivasi sistem limbik yang memengaruhi fungsi kognitif (proses pemahaman). ${ }^{11}$ Musik jazz dapat meningkatkan kecerdasan emosi/ Emotional Quotient (EQ) karena jenis musik ini memiliki irama teratur sehingga tercipta rasa tenang dan emosi pun menjadi stabil. Seseorang yang memiliki kecerdasan emosi yang baik cenderung pandai dalam mengatur suasana hati sehingga meningkatkan motivasi, energi, dan kepercayaan diri saat konsentrasi dan proses pemahaman membaca berlangsung., ${ }^{4,13}$

\section{Simpulan}

Simpulan dari penelitian ini adalah mendengarkan background-music klasik dan jazz dapat meningkatkan konsentrasi dan reading comprehension pada wanita dewasa muda, namun tidak terdapat perbedaan peningkatan kemampuan konsentrasi dan reading comprehension antara kedua jenis musik tersebut.

\section{Daftar Pustaka}

1. Woolley G. Reading Comprehension: Assisting Children with Learning Difficulties New York: Springer; 2011.

2. Grimonia E. Dunia Musik: Sains Musik untuk Kebaikan Hidup Farida A, Umbara YS, editors. Bandung: Nuansa Cendekia; 2014.

3. Ferreri L, Verga L. Benefits of music on verbal learning and memory: How and when does it work? An Interdisc Jour.2016;34:167-82.

4. Nichols B, Wöllner C, Halpern A. Score one for jazz: Working memory in jazz and classic musicians. Music, Mind, and Brain. 2018;28:101-7.

5. Windura S. Brain management series for learning strategy: Be an absolute genius! Elex Media Komputindo; 2008.

6. Ahmed SA, Rani DDE, Sattar DSA. Alpha activity in EEG and Intelligence. Int J Adv Inform Tech. 2012; 2(1):27-36

7. Yulissusanti DA, Widodo PB, Rusmawati D. Pengaruh musik jazz terhadap kecerdasan emosi pada remaja SMA Kelas XI. Empati. 2013; 2(3).

8. Gamso, MN. An aural learning project assimilating Jazz education methods for traditional applied pedagogy. Mus Educ Jour. 2011;98:61-7.

9. Guyton, AC, \& Hall, JE. Textbook of Medical Physiology 11th ed. Singapore: Elsevier. 2014.

10. Sherwood, L. Human physiology: From cells to systems 7th ed..Belmont,CA: Brooks/Cole. 2010.

11. Campbell DG. The Mozart Effect : taping the power of music to heal the body, strenghten the mind and unlock the creative spirit Jakarta: Gramedia. 2009. 


\section{Research Article}

12. Rashidi N, Faham F. The effect of classic music on the reading comprehension of Iranian Students. Theor Pract Lang Stu. 2011; 1(1):74-82.

13. Alexander J, Firouzbakht P, Glennon L, Lang M. Effects of music type on reading comprehension performance and other physiological factors. J Adv Stu Sci. 2012; 1(01):1-11.

14. Geethanjali B, Adalarasu K, Rajsekaran R. Impact of Music on Brain Function during Mental Task using Electroencephalography. World Academy of Science, Engineering and Technology. 2012; 66: p. 883-7.Freeburne CM, Fleischer MS. The Effect of Music Distraction Upon Reading Rate and Comprehension. The Journal of Educational Psychology. 1952;: p. 101-9.

15. Sweeney SM. Effects of Music on Reading Comprehension : Genres of Music vs. Lyrical and Non Lyrical. 2012. 